\title{
An english-language teaching plan for children in the internet of things environment
}

\author{
Mohammad Moradi, Kheirollah Rahsepar Fard \\ Information Technology and Computer Engineering, University of Qom, Qom, Iran
}

\begin{tabular}{|c|c|}
\hline Article Info & ABSTRACT \\
\hline Article history: & An important topic that need to investigate is teaching of English language. \\
\hline Received Aug 18, 2018 & $\begin{array}{l}\text { In most educational methods, a series of pre-defined and fixed subjects are } \\
\text { used for all individuals. There is also less attention paid to modern methods }\end{array}$ \\
\hline Revised Dec 7, 2018 & in education of English language. In this paper we present an application as a \\
\hline Accepted Dec 15, 2018 & $\begin{array}{l}\text { modern method in education of English language. In the proposed algorithm } \\
\text { that is in the internet of things environment, has paid attention to teaching of }\end{array}$ \\
\hline Keywords: & $\begin{array}{l}\text { English language, includes the use of objects, images, pronunciation, the use } \\
\text { of vocabulary in sentences and texts, the relevance of content with the age }\end{array}$ \\
\hline Education & $\begin{array}{l}\text { and culture of the child, and the relevance of the content of the courses and } \\
\text { exercises with the amount of learning each child. }\end{array}$ \\
\hline
\end{tabular}

Copyright () 2019 Institute of Advanced Engineering and Science. All rights reserved.

\section{Corresponding Author:}

Kheirollah Rahsepar Fard,

Information Technology and Computer Engineering,

University of Qom, Qom, Iran.

Email: rahseparfard@gmail.com

\section{INTRODUCTION}

Learning is a fundamental rule in life. In the world, everyone believes that owe its learning from its initiate, complex and specialized functions [1]. An important topic you need to learn from a child is English language. The English language recognized as an international language is a means of communication between the various nations [2]. Today, English language has an important role to play in business, politics, economics and technology. Therefore, it is necessary to expand English language proficiency [3].

How to teach English language, especially teaching it to children, is a topic that requires to investigate. The methods use a predetermined framework and procedures for teaching English language. For instance: Teaching is a course where the content of these lessons and their arrangement are preset. However, sometimes it is necessary to change the next lesson, depending on the amount and type of material that the child has learned in a lesson. Therefore the new lesson will be helpful and complementary to the topics in which he is weak. In this paper, by considering the benefits of modern technologies in educational English language, we present an application in the internet of things environment. The present method has various options, more motivate and availability and so on. Hence, ordering and content of lessons and necessary practices relate to amount and type of his/her learning. It is good for a child to pay attention to necessity of learning styles for application. Types of learning styles based on sensory perceptions are divided into three categories: visual learning style, audio learning style, and kinetic-linguistic learning style. In the visual learning style, people remember the information by observing and combining images with information. This style is about 65 percent of the population. In the audio learning style, people tend to deal with music and sounds more than 30 percent of the population. In a kinetic-linguistic learning style, people use their own body and sensation to learn and memorize information. This style covers about 5 percent of the population. Therefore, due to the high volume of visual and audio learning styles in the design of the educational 
application, these necessity of two styles have been given special attention. Several studies have been conducted on English language teaching, summarized in Table 1.

Table 1. Related Works of English Language Teaching

\begin{tabular}{|c|c|c|c|c|}
\hline author & $\begin{array}{l}\text { Publishing } \\
\text { year }\end{array}$ & Title & Instrument used for analysis & summary of results \\
\hline $\begin{array}{c}\text { Parviz } \\
\text { Birjandi \& } \\
\text { Shirin Abadi } \\
\text { Khah [4] }\end{array}$ & 2001 & $\begin{array}{l}\text { The impact of using } \\
\text { language games on } \\
\text { learning English } \\
\text { vocabulary }\end{array}$ & T test & $\begin{array}{l}\text { The use of the game has improved } \\
\text { learning }\end{array}$ \\
\hline $\begin{array}{c}\text { Zohreh } \\
\text { Sajjad [5] }\end{array}$ & 2005 & $\begin{array}{l}\text { The Effect of } \\
\text { English Language } \\
\text { Teaching Skills on } \\
\text { Students' } \\
\text { Communication } \\
\text { Skills in the Age of } \\
\text { Information } \\
\text { Technology. }\end{array}$ & $\begin{array}{l}\text { This research was descriptive } \\
\text { type and the statistical } \\
\text { population of this study was } \\
\text { English language secondary } \\
\text { school teachers of Isfahan. }\end{array}$ & $\begin{array}{l}\text { Audience and verbal skills in } \\
\text { teaching English language are more } \\
\text { important for teachers. They } \\
\text { believed that reinforcing hearing } \\
\text { and speech skills would also } \\
\text { enhance other skills. }\end{array}$ \\
\hline $\begin{array}{l}\text { Ezzatollah } \\
\text { Ghenaat } \\
\text { pishe [6] }\end{array}$ & 2006 & $\begin{array}{l}\text { Study of Persian } \\
\text { Language } \\
\text { Interaction in } \\
\text { English Language } \\
\text { for secondary } \\
\text { Learners' }\end{array}$ & $\begin{array}{l}\text { For data analysis, descriptive } \\
\text { study method has been used. }\end{array}$ & $\begin{array}{l}\text { Interference with mother tongue in } \\
\text { learning English language is the } \\
\text { main cause of deterrence in } \\
\text { learning this language }\end{array}$ \\
\hline $\begin{array}{l}\text { Mahdieh } \\
\text { Jamali } \\
\text { paghaleh [7] }\end{array}$ & 2008 & $\begin{array}{l}\text { Students and their } \\
\text { inability to speak } \\
\text { English language }\end{array}$ & Library method & $\begin{array}{l}\text { The causes of poor English } \\
\text { language proficiency are students } \\
\text { 'misconceptions about teaching, } \\
\text { teachers' inability to speak, lack of } \\
\text { speaking opportunities, fluctuating } \\
\text { classes, lack of motivation in } \\
\text { students, and the way of } \\
\text { examination is conducted. }\end{array}$ \\
\hline $\begin{array}{l}\text { Mahvash } \\
\text { abbasi \& }\end{array}$ & 2009 & $\begin{array}{c}\text { A Survey of } \\
\text { Teaching-Learning }\end{array}$ & Descriptive survey & $\begin{array}{l}\text { The role of cultural-social, } \\
\text { individual and educational factors }\end{array}$ \\
\hline Gholamreza & & Problems of English & & is more than average, and the \\
\hline Ahmadi \& & & Language at the & & factors of the phonetic system, the \\
\hline $\begin{array}{l}\text { Ahmad reza } \\
\text { lotfi [8] }\end{array}$ & & $\begin{array}{l}\text { High School Level } \\
\text { in the City of } \\
\text { Isfahan From } \\
\text { Teachers' Point of } \\
\text { View }\end{array}$ & & $\begin{array}{l}\text { vocabulary of Persian language and } \\
\text { Persian grammar did not have } \\
\text { much effect on the problems of } \\
\text { teaching the English language. }\end{array}$ \\
\hline $\begin{array}{l}\text { Gholamreza } \\
\text { Azarpouyeh } \\
\text { dinaki \& } \\
\text { Sareh } \\
\text { Azarpouyeh } \\
\text { [9] }\end{array}$ & 2013 & $\begin{array}{l}\text { A study on the role } \\
\text { of educational } \\
\text { illustration in } \\
\text { English language } \\
\text { teaching }\end{array}$ & $\begin{array}{l}\text { The research method was the } \\
\text { theoretical, and the method of } \\
\text { data collection was a library. }\end{array}$ & $\begin{array}{l}\text { The images enhance and improve } \\
\text { the quality of English language } \\
\text { learning by applying attractive } \\
\text { design and color, and revealing and } \\
\text { clarifying the educational content. }\end{array}$ \\
\hline $\begin{array}{l}\text { Hadi Sarani } \\
\text { \& Mohsen } \\
\text { Ayati \& } \\
\text { Fatemeh } \\
\text { Naderi [10] }\end{array}$ & 2014 & $\begin{array}{l}\text { The effects of } \\
\text { teaching English } \\
\text { language course via } \\
\text { phone and email on } \\
\text { learning and } \\
\text { achievement's } \\
\text { motivation }\end{array}$ & $\begin{array}{l}\text { In terms of research type, it was } \\
\text { applied and in terms of method, } \\
\text { was semi-experimental with } \\
\text { pre-test and post-test design } \\
\text { and control group. }\end{array}$ & $\begin{array}{l}\text { The method of teaching through } \\
\text { mobile and e-mail has had a } \\
\text { positive impact on the learning and } \\
\text { motivation of student progress in } \\
\text { English language. }\end{array}$ \\
\hline $\begin{array}{l}\text { Saefurrohma } \\
\text { n \& Elvira S. } \\
\text { Balinas [11] }\end{array}$ & 2016 & $\begin{array}{l}\text { English Teachers } \\
\text { Classroom } \\
\text { Assessment } \\
\text { Practices }\end{array}$ & questionnaire & $\begin{array}{l}\text { The study found that both Filipino } \\
\text { and Indonesian junior high school } \\
\text { English teachers used assessment } \\
\text { for learning as the main purpose of } \\
\text { assessment. }\end{array}$ \\
\hline $\begin{array}{c}\text { Kornwipa } \\
\text { Poonpon [12] }\end{array}$ & 2017 & $\begin{array}{l}\text { Enhancing English } \\
\text { skills through } \\
\text { project-based } \\
\text { learning }\end{array}$ & A semi-structured interview & $\begin{array}{c}\text { Interdisciplinary-based project } \\
\text { should be implemented in a } \\
\text { language classroom to enhance the } \\
\text { learners' English skills }\end{array}$ \\
\hline $\begin{array}{l}\text { Mona Kamal } \\
\text { Ibrahim \& } \\
\text { Yehia A. } \\
\text { Ibrahim [13] }\end{array}$ & 2017 & $\begin{array}{l}\text { Communicative } \\
\text { English language } \\
\text { teaching in Egypt: } \\
\text { Classroom practice } \\
\text { and challenges }\end{array}$ & $\begin{array}{l}50 \text { classroom observations, } 100 \\
\text { questionnaire responses from } \\
\text { teachers, and } 10 \text { face-to-face } \\
\text { interviews with follow-up } \\
\text { discussion sessions }\end{array}$ & $\begin{array}{l}\text { Despite of all the CELT-demanding } \\
\text { policies of the Egyptian Ministry of } \\
\text { Education, practising teachers are } \\
\text { mostly unaware of CELT principles } \\
\text { and know-how implementation }\end{array}$ \\
\hline
\end{tabular}


In previous researches in accordance with the educational content of each lesson and the necessary training with the amount and type of subject that has ever been learned, as well as the use of the internet of things as a place for training and testing is not paid attention. The contents of each lesson and practice are fixed. In this paper, an application is presented in which the modern methods of teaching English language are considered and the child is considered with the content and training of each subject in terms of the amount and type of materials received. For this purpose, the internet of things has been assisted. In the following, definitions of the internet of things and its applications will be expressed. Then will be presented to the proposed application in the internet of things environment.

\section{RESEARCH METHOD}

New technologies that can help us to design an application of English language is the internet of things, a term that was introduced by Quinn Ashton in 1999. On the internet, objects can be connected to the internet other than human beings. Existing entities and objects will automatically be able to communicate with each other and exchange the required data [14]. By using the internet of things, all objects are interconnected, which can be controlled and managed with the help of apps [15]. In fact, the internet of things is a new concept in the world of technology and communications, which, as a modern technology, provides the ability to send data through communication networks, for every facet [16], [17]. The internet of things has many applications in various fields and sciences, including smart cities, intelligent agriculture, transportation, health, energy, and so on. For example, Navulur investigated the agricultural management through wireless sensors and internet of things [18]. For another example Gunawan have proposed a smart home system using internet of things and four types of sensors, including PIR, temperature, ultrasonic, and smoke gas sensor for automatic environmental control and intrustion detection [19].

The proposed English language education program consists of three parts: education, practice, and test, which aims to conduct a test for determining the content of instruction and practice the next lesson according to the amount of learning a child in the current lesson. In the section on how English language education, pictures are used to create a mental image of children who have visual styles. The pronunciation of the word is used for correct speech and also for the better learning of children with audible style. Also, after a preliminary study, a text containing all the new vocabulary is used to review them. Given the fact that children are sensitive at an early age, the expert has been used to examine the relevance of vocabulary and images with age of child. Also, since the child's parents are more aware of their child's characteristics and their culture, they also have an option to examine the vocabulary and images.

In order to determine the content of the next lesson, the selected text for review and determination of the necessary training, the child needs to be tested for the subjects that have been trained so far. If the child earns a threshold score, the test result for the base, which contains all the contents of the English language teaching resource, is sent. The system will adjust to the amount of child's learning, the subjects child have learned and the issues child have difficulty, the necessary changes to the new lesson and the type of training child will need. For example, if a child had difficulty in words, he would try to include more prefixed and extended words in the next lesson. It is also used in the text of choice to review the problematic term and to identify other exercises that help to learn more problematic words. But if the child does not earn a threshold score, he will be referred to the instructor for further studies and necessary training. Also, the material that has been assigned to teach the child has been sent along with the child's test results for the coach (in order to better educate the child). Then the child is re-tested from the student's lessons and, depending on whether or not to score at least, the cycle continues until all the instructional materials are completed.

In addition to the vocabulary images used in the education section, objects are also used in training, practice, and test areas to learn and maintain a better vocabulary in mind. For this purpose, tags are defined for each object. For example, a label for refrigerator and so on. During testing, if a label for the word is defined in the program, the child can closed to the object after hearing the word, and, therefore, communicate that object with the smart phone object (or tablet, etc.) to determine the meaning the word. Also, the number of errors in determining the meaning of the word by objects can also be recorded in the program. In the education section, as the child closed to each object, the object introduces itself. Also, in the practice section, the child can closed to the objects and express the pronunciation of the object to practice the meaning and pronunciation of the word, which is determined correctly or incorrectly in the program, and helps the child to express the correct pronunciation and meaning of the object. Figure 1 shows a suggested application. 


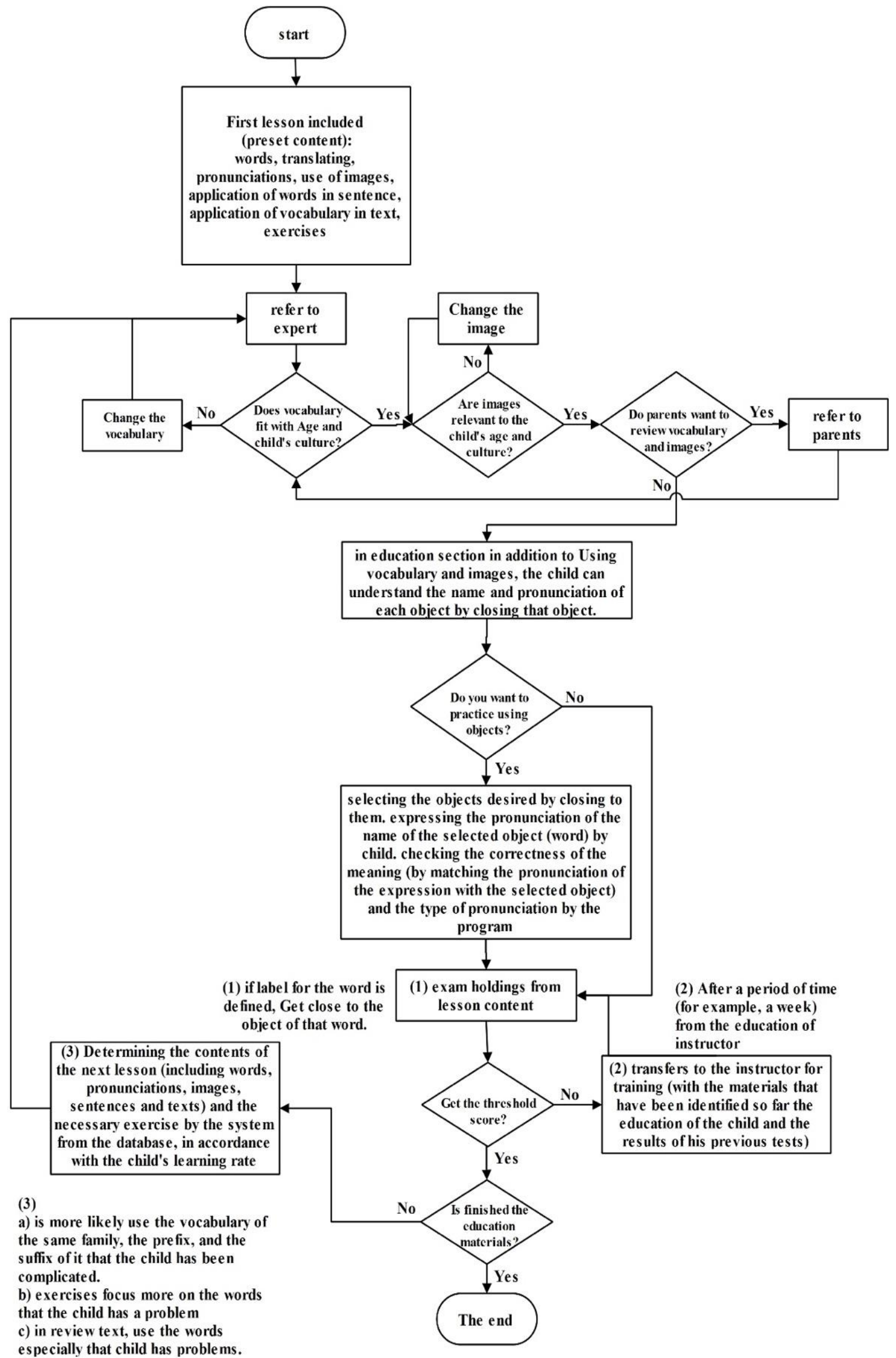

Figure 1. An Overview of the Suggested Language Learning Program 


\section{RESULTS AND DISCUSSION}

As stated, and as shown in Figure 1, the proposed application is intended for teaching, from various methods such as image, the use of objects, the use of words in the sentence, and the use of text for review. This takes into account the visual and auditory styles. A case that has been ignored by many of the related work in the field of English language education. Also, in proposed application the attention has been paid to determining the next educational content and the necessary training in proportion to the amount of child's learning; a case that has ignored in previoused work of teaching English language. This method makes the type of education appropriate to the amount of learning for each child and avoids fixed and generalized content for all children.

In previous studies, modern technologies for teaching English have been used rarely. In this paper, the Internet of Things is used as a modern technology in training, practice, and testing areas. The use of the internet of things due to the confrontation of the child with objects increases the visual and auditory styles. As a result, English vocabulary is more in the child's mind and the child learns more quickly. In addition, it motivates the child and encourages him to learn more.

\section{CONCLUSION}

In this paper, the importance of teaching English language, especially from childhood, was expressed. For this reason, the application was proposed due to the benefits of modern educational methods including diverse facilities, persuasion and high availability. In design of an application in the internet of things environment, both the teaching of English language as well as the introduction of the next lesson and the necessary training of each child in proportion to the extent of learning the previous lessons were considered.

It also attempted to use education tailored to the visual and audio learning style that includes the largest number of subjects. Therefore, various methods of teaching, practicing and proportioning, pronunciation, the use of vocabulary in sentences and the review of vocabulary in the text, the test of each lesson, including the use of objects, the use of image content with the age and culture of the child, as well as avoiding the constant content and Educational training was used for each child, which is a suggested application benefit. Finally, we conclude that internet of things can increase the interaction between child and others.

\section{REFERENCES}

[1] Sharafi, S. The Responsibilities of Parents Having Children with Learning Disorders. Journal of Exceptional Education, 2012; 4(112): 45-54.

[2] Nooshinfar, V. (2001). Language, gender, community. Master's thesis, Ferdowsi University of Mashhad, Faculty of Literature and Humanities.

[3] Numan, D., \& Carter, D. (2001). Teaching English to speakers of other languages. Cambridge: CUP.

[4] Birjand, P. \& Abadi Kah, Sh. (2001). The impact of using language games on learning English vocabulary. Language Learning Growth, (63): 4-9.

[5] Sajjad, Z. (2005). The Effect of English Language Teaching Skills on Students' Communication Skills in the Age of Information Technology. University of Isfahan.

[6] Ghenaat Pisheh, E. (2006). Study of Persian Language Interaction in English Language for secondary Learners'. Language Learning Growth.

[7] Jamali Paghaleh, M. (2008). Students and their inability to speak English. Language Learning Growth.

[8] Abbasi, M., Ahmadi, Gh. \& Lotfi, A. A Survey of Teaching-Learning Problems of English Language at the High School Level in the City of Isfahan from Teachers' Point of View. Research in Curriculum Planning, 2009; 1(22), 141-156.

[9] Azarbouyeh, Gh. \& Azarbouyeh, S. A study on the role of educational illustration in English language teaching. The First National Conference in Teaching English, Literature and Translation. 2013.

[10] Sarani, H., Ayati, M. \& Naderi, F. The effects of teaching English language course via phone and email on learning and achievement's motivation. Quarterly Journal of Research and Planning in Higher Education, 2014; 20(3): 141-159.

[11] Saefurrohman, S., \& Balinas, E. S. English Teachers Classroom Assessment Practices. International Journal of Evaluation and Research in Education (IJERE), 2016; 5(1), 82-92.

[12] Poonpon, K. (2017). Enhancing English skills through project-based learning. The English Teacher, 10.

[13] Ibrahim, M. K., \& Ibrahim, Y. A. Communicative English language teaching in Egypt: Classroom practice and challenges. Issues in Educational Research, 2017; 27(2), 285.

[14] Evans, D. The internet of things: How the next evolution of the internet is changing everything. CISCO white paper, 2017: 1-11.

[15] Ashton, K. That 'internet of things' thing. RFID Journal, 2009; 22(7): 97-114.

[16] Chui, M., Löffler, M. \& Roberts, R. The internet of things. McKinsey Quarterly, 2010; 2: 1-9. 
[17] Fox, G. C., Kamburugamuve, S. \& Hartman, R. D. Architecture and measured characteristics of a cloud based internet of things. In Collaboration Technologies and Systems (CTS), 2012 International Conference on. pp. 6-12. IEEE.

[18] Navulur, S., Sastry, A. S. C. S., Prasad, M. G., \& Prasad, G. Agricultural management through wireless sensors and internet of things. International Journal of Electrical and Computer Engineering (IJECE), 2017; 7(6), 3492-3499.

[19] Gunawan, T. S., Yaldi, I. R. H., Kartiwi, M., \& Mansor, H. Performance Evaluation of Smart Home System using Internet of Things. International Journal of Electrical and Computer Engineering (IJECE), 2018; 8(1), 400-411. 